\title{
Preoperative antithrombin III activities and lipoprotein concentrations as predictors of venous thrombosis in patients with fracture of neck of femur
}

\author{
JH WINTER, A FENECH, B BENNETT, AS DOUGLAS
}

From the Department of Medicine, University of Aberdeen, Foresterhill, Aberdeen, Scotland

SUMMARY The presence or absence of venous thrombosis was determined by the technique of $\dot{\omega}^{\circ}$ autologous ${ }^{11}$ indium-labelled platelets in 64 patients following reduction and fixation of fractures of the neck of femur. Venous thrombosis was found in $41(64 \%)$ of these patients. Compared to the thrombosis-negative group, the thrombosis-positive group had a significantly lower mean serum antithrombin, and higher mean antithrombin consumption during clotting in the immediate preoperative period. No significant differences were seen between the two groups in plasma ATIII activities, fibrinogen, alpha-2-macroglobulin, serum lipoproteins or age. Significant correlations were seen between ATIII activities and lipoprotein fractions; these are discussed.

Antithrombin III (ATIII) is a major physiological inhibitor of the coagulation system and a deficiency of this plasma protein is associated with a clear predisposition to venous thrombosis. ${ }^{1}$ Attempts to predict venous thrombosis after general surgery by the preoperative measurement of ATIII activities have not proved successful, ${ }^{2}{ }^{3}$ although in two groups of patients undergoing total hip replacement mean levels of ATIII activity were lower preoperatively in those patients found to have thrombosis postoperatively when compared to those in whom thrombosis was not found; $4^{45}$ in addition a preoperative level of ATIII activity of less than $80 \%$ of normal was associated with an almost $100 \%$ incidence of postoperative venous thrombosis.

The absence of a clear relation between preoperative plasma ATIII and the incidence of postoperative venous thrombosis indicates that within a broad normal range ATIII levels do not influence the incidence of postoperative venous thrombosis, or that other factors may influence the activity of ATIII so that the activity measured in the laboratory is not a clear reflection of that in vivo. We have recently reported data which suggest that lipoprotein fractions may influence the activity of ATIII. ${ }^{6}$ The clinical importance of any relation between lipoproteins and ATIII can be decided only by their study in a patient group. Accordingly we have studied various ATIII activities and serum lipoproteins in a group of

Accepted for publication 22 December 1982 patients before operative reduction and fixation of fracture of the neck of femur. The presence or absence of deep venous thrombosis in these patients was determined postoperatively by the technique of autologous ${ }^{11}$ indium-labelled platelets; this technique has been shown to be sensitive and accurate in the diagnosis of deep venous thrombosis in such patients when compared to ascending venography. ${ }^{7}$

\section{Patients and methods}

\section{PATIENTS}

The study group consisted of 64 patients with fracture of the neck of femur with a mean age of $75 \mathrm{yr}$, range 43-95 yr. A fasting blood sample was taken between 0800 and $0900 \mathrm{~h}$ on the day of operation when the patient had fasted overnight. Plasma and serum were prepared and separated as described previously, ${ }^{6}$ and stored at $-70^{\circ} \mathrm{C}$ until assayed. The interval between admission and operation varied between none and three days. Autologous platelets were labelled with ${ }^{11}$ indium between seven and 10 days after operation; scanning of the lower limbs and pelvis was performed 24 hours after labelling.

ATIII and alpha-2-macroglobulin antigen were measured by radial immunodiffusion in agarose using commercially available antiserum (Sigma, St Louis, USA and Behringwerke Marburg, West Germany, respectively). Heparin cofactor activity was measured by the method of Abildgaard, Lie and $\emptyset_{\text {degard }^{8}}$ using Chromozym TH (Boehringer). 
Progressive antithrombin activity was measured by the method of Abildgaard, Gravem and Godal ${ }^{9}$ and antifactor Xa activity was measured by the initial rate method of $\varnothing$ degard, Lie and Abildgaard ${ }^{10}$ in the absence of heparin using S2222 (Kabi AB, Stockholm).

Specific ATIII activity is derived from the division of functional by antigenic activity and is designed to give a measure of activity per unit of protein.

Clottable fibrinogen was assayed by the method of Ogston and Ogston. ${ }^{11}$

Serum lipids were separated by a heparin precipitation technique and cholesterol and triglyceride were assayed by an enzymatic technique as previously described. ${ }^{6}$ High density lipoprotein (HDL) cholesterol estimations using the heparin separation technique are reported to agree very closely with estimations using an ultracentrifugation separation technique $^{12}$ and in our laboratory we have found close agreement between estimations using these techniques.

\section{Results}

Venous thrombosis was found in the postoperative period in $41(64 \%)$ of the 64 patients. When compared to the group of patients in whom venous thrombosis was not detected those patients in whom it was detected were found to have preoperatively a significant decrease in serum progressive antithrombin activity, serum heparin cofactor activity, and a significant increase in the consumption of progressive antithrombin activity during clotting in vitro (Table 1).

No significant differences between the two groups were seen in the mean levels of lipoprotein fractions, fibrinogen, alpha-2-macroglobulin or age although a higher mean age and serum triglyceride and lower mean serum high density lipoprotein cholesterol were seen in the patients in whom venous thrombosis was detected.

Considered as a single group, significant positive correlations were seen between plasma ATIII

Table 1 ATIII activities in patients in whom thrombosis was detected and patients in whom thrombosis was not detected postoperatively

\begin{tabular}{|c|c|c|c|c|c|c|}
\hline & \multicolumn{3}{|c|}{$\begin{array}{l}\text { No venous thrombosis detected } \\
(n=23)\end{array}$} & \multicolumn{3}{|c|}{$\begin{array}{l}\text { Venous thrombosis detected in } \\
\text { postoperative period }(n=41)\end{array}$} \\
\hline & Mean & $\begin{array}{l}\text { Standard } \\
\text { deviation }\end{array}$ & Range & Mean & $\begin{array}{l}\text { Standard } \\
\text { deviation }\end{array}$ & Range \\
\hline $\begin{array}{l}\text { Plasma ATIII antigen } \% \\
\text { Serum ATIII antigen \% } \\
\text { Plasma progressive ATIII activity \% } \\
\text { Serum progressive ATIII activity } \% * *\end{array}$ & $\begin{array}{l}83 \cdot 72 \\
64 \cdot 89 \\
82 \cdot 20 \\
51 \cdot 74\end{array}$ & $\begin{array}{l}8 \cdot 80 \\
6 \cdot 40 \\
6 \cdot 71 \\
9 \cdot 89\end{array}$ & $\begin{array}{l}67-97 \\
54-73 \\
69-96 \\
35-66\end{array}$ & $\begin{array}{l}83 \cdot 07 \\
60 \cdot 28 \\
80 \cdot 60 \\
44 \cdot 50\end{array}$ & $\begin{array}{r}12 \cdot 74 \\
11 \cdot 19 \\
10 \cdot 14 \\
9 \cdot 28\end{array}$ & $\begin{array}{l}60-114 \\
47-77 \\
64-103 \\
27-68\end{array}$ \\
\hline $\begin{array}{l}\text { Consumption of progressive ATIII activity } \\
\text { on clotting \%* } \\
\text { Specific progressive ATIII activity } \\
\text { Plasma heparin cofactor activity } \% \\
\text { Serum heparin cofactor activity } \%^{* *}\end{array}$ & $\begin{array}{c}30 \cdot 38 \\
0.988 \\
86 \cdot 87 \\
54 \cdot 48\end{array}$ & $\begin{array}{l}8 \cdot 57 \\
0 \cdot 082 \\
7 \cdot 87 \\
11 \cdot 20\end{array}$ & $\begin{array}{l}16-42 \\
0 \cdot 869-1 \cdot 18 \\
73-101 \\
35-77\end{array}$ & $\begin{array}{l}36 \cdot 1 \\
0 \cdot 978 \\
85 \cdot 10 \\
47 \cdot 95\end{array}$ & $\begin{array}{c}10 \cdot 78 \\
0 \cdot 099 \\
14 \cdot 59 \\
9 \cdot 72\end{array}$ & $\begin{array}{l}17-68 \\
0 \cdot 786-1 \cdot 22 \\
54-130 \\
27-68\end{array}$ \\
\hline $\begin{array}{l}\text { Consumption of heparin cofactor activity } \\
\text { on clotting \% } \\
\text { Plasma specific heparin cofactor activity } \\
\text { Plasma anti-factor Xa activity \% } \\
\text { Plasma specific anti-factor Xa activity }\end{array}$ & $\begin{array}{r}32 \cdot 05 \\
1 \cdot 040 \\
104 \cdot 63 \\
1 \cdot 249\end{array}$ & $\begin{array}{c}10 \cdot 90 \\
0.097 \\
8 \cdot 87 \\
0.073\end{array}$ & $\begin{array}{l}13.53 \\
0.883-1.31 \\
89-125 \\
1.14-1.46\end{array}$ & $\begin{array}{c}37 \cdot 29 \\
1 \cdot 028 \\
102 \cdot 51 \\
1 \cdot 241\end{array}$ & $\begin{array}{c}13 \cdot 64 \\
0 \cdot 110 \\
14 \cdot 43 \\
0 \cdot 102\end{array}$ & $\begin{array}{l}16 \cdot 80 \\
0 \cdot 710-1 \cdot 26 \\
82-140 \\
1 \cdot 05-1.43\end{array}$ \\
\hline
\end{tabular}

ATII activities in patients with fracture of the neck of femur in whom deep venous thrombosis was or was not detected by the indium labelled platelet technique postoperatively.

p value for difference between two groups $*<0.05$

Table 2 Correlations between ATIII activities and lipoprotein fractions in all patients

\begin{tabular}{|c|c|c|c|}
\hline & $\begin{array}{l}\text { Total serum } \\
\text { cholesterol }\end{array}$ & $\begin{array}{l}\text { High density } \\
\text { lipoprotein } \\
\text { cholesterol }\end{array}$ & $\begin{array}{l}\text { Heparin } \\
\text { precipitable } \\
\text { lipoprotein } \\
\text { cholesterol }\end{array}$ \\
\hline $\begin{array}{l}\text { Plasma ATIII antigen } \\
\text { Plasma antifactor Xa activity } \\
\text { Specific plasma progressive antithrombin activity } \\
\text { Consumption of progressive antithrombin activity on clotting } \\
\text { Consumption of heparin cofactor activity on clotting }\end{array}$ & $\begin{array}{l}+0 \cdot 44^{*} \\
+0 \cdot 42^{*} \\
+0 \cdot 38^{*}\end{array}$ & $\begin{array}{l}+0.45^{* *} \\
+0.47^{* *}\end{array}$ & $-0 \cdot 51^{* *}$ \\
\hline
\end{tabular}

Correlation seen between ATIII activities and lipoprotein fractions:

* $p<0.01$

$* * \mathrm{p}<0 \cdot 001$. 
activities and both total cholesterol and HDL cholesterol, and between the consumption of ATIII activities and total serum cholesterol (Table 2).

A significant negative correlation was seen between specific plasma progressive antithrombin activity and serum heparin precipitable lipoprotein cholesterol (Table 2).

\section{Discussion}

These data give little support to the suggestion that plasma ATIII and/or plasma lipoprotein fractions are of major importance in the pathogenesis of deep venous thrombosis detected postoperatively in patients after surgery to fracture of the neck of femur; nevertheless this study does not rule out some contribution of these agents since a significant difference was seen in serum ATIII and ATIII consumption during clotting between those groups with and without thrombosis, and minor non-significant differences were seen in serum lipids. We are unable to confirm in patients with fracture of neck of femur the findings of Sagar and colleagues and of Stamatakis and colleagues ${ }^{4} 5$ who found that in patients undergoing total hip replacement a preoperative ATIII level of less than $80 \%$ was associated with the finding of venous thrombosis in the postoperative period in almost $100 \%$ of patients. However, a major difference may exist between these two groups of patients because, as has recently been reported from this department ${ }^{13}$ the incidence of preoperative venous thrombosis in patients with fracture of neck of femur is high (presumably occurring in the interval between fracture and surgery) whereas in patients before total hip replacement it might reasonably be expected to be very low. In this study the interval between fracture and operation did not appear to influence the incidence of venous thrombosis.

Nilson and colleagues ${ }^{14}$ reported a significant decrease in preoperative serum ATIII in those patients undergoing total hip replacement who were found to have venous thrombosis in the postoperative period when compared to those free from thrombosis. These authors also report a significantly higher fibrinogen level in the thrombosis positive patients and found a highly significant difference in the quotient of fibrinogen to serum antithrombin. We have found no significant difference in plasma fibrinogen between thrombosis-positive and thrombosis-negative groups, and our study has not indicated any value for this quotient in these patients.

Mean plasma ATIII levels in our patients were considerably below the normal ranges for our laboratory; it is possible that fracture of the femur caused some depression of the ATIII levels since trauma in the form of surgical operations commonly leads to the degree of depression of plasma ATIII seen in our patients. ${ }^{15}$

Interesting correlations were seen when ATIII activities were expressed in terms of activity per unit of ATIII antigen (specific activity) (Table 2). Plasma specific progressive antithrombin activity showed a significant negative correlation with heparin precipitable lipoprotein cholesterol. No such correlation was seen for plasma specific heparin cofactor activity. Yin ${ }^{16}$ has reported that phospholipid protects factor Xa from inhibition by ATIII in vitro and that this inhibition may be overcome by introducing heparin into the system. Thus it is possible that in the assay of progressive antithrombin activity these lipoproteins act in such a way to interfere with the inhibition of protease by ATIII, whereas in the assay $\partial$ of heparin cofactor activity with heparin in the system these influences do not operate. The consumption of ATIII activity during clotting in vitro demon- $\vec{z}$ strated a positive correlation with serum cholesterol which supports the suggestion that lipoproteins may $\overrightarrow{0}$ influence the ATIII-protease interaction during $\underset{\omega}{\infty}$ clotting.

This study indicates that preoperative measurement of ATIII activities and of lipoproteins does not predict which of those patients with fracture of neck of femur will have postoperative venous thrombosis; the lack of predictive value may in part be due to the high incidence of preoperative venous thrombosis in these patients. Nevertheless these data suggest that lipoproteins may influence ATIII activities and the consumption of ATIII during clotting, and indicate that further examination of ATIII-proteaselipoprotein interactions may be of value.

We are indebted to the orthopaedic surgeons of the Aberdeen Hospitals for allowing us to study their patients. Miss Judith Smith kindly performed the lipoprotein and fibrinogen analyses. We are grateful to Mrs Sandra Short for typing the manuscript.

\footnotetext{
References

${ }^{1}$ Egeberg $O$. Inherited antithrombin deficiency causing thrombophilia. Thrombosis et Diathesis Haemorrhagica 1965;13:516-30.

${ }^{2}$ Gallus AS, Hirsh J, Gent M. Relevance of preoperative and $\stackrel{0}{ }$ postoperative blood tests to postoperative leg vein thrombosis. Lancet 1973;ii:805-9.

${ }^{3}$ Gunn IG. Anti-factor $\mathrm{Xa}$ as a predictor of postoperative deep vein thrombosis in general surgery. Br J Surg 1979;66:636.

${ }^{4}$ Sagar S, Nairn D, Stamatakis JD, et al. Efficacy of low-dose heparin in prevention of extensive deep-vein thrombosis in patients undergoing total-hip replacement. Lancet $\mathbb{Q}$ 1976;1:1151-4.

${ }^{5}$ Stamatakis JD, Lawrence D, Kakkar VV. Surgery, venous
}

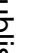


thrombosis and anti-Xa. Br J Surg 1977;64:709-11.

- Winter JH, Bennett B, McTaggart F, Douglas AS. Lipoprotein fractions and antithrombin 111 consumption during clotting. Thromb Haemost 1982;47:236-8.

' Fenech A, Hussey JK, Smith FW, Dendy PP, Bennett B, Douglas AS. The diagnosis of deep vein thrombosis using autologous indium ("'In) labelled platelets. Br Med J 1981;282:1020-2.

${ }^{8}$ Abildgaard U, Lie M, Ødegard OR. Antithrombin (heparin cofactor) assay with 'new' chromogenic substrates (S-2238 and Chromozym-TH). Thromb Res 1977;11:549-53.

9 Abildgaard U, Gravem K, Godal HC. Assay of progressive antithrombin in plasma. Thrombosis et Diathesis Haemorrhagica 1970;24:224-9.

${ }^{10} \emptyset$ degard OR, Lie M, Abildgaard U. Antifactor Xa activity measured with amidolytic methods. Haemostasis 1976;5:265-75.

"Ogston CM, Ogston D. Plasma fibrinogen and plasminogen levels in health and in ischaemic heart disease. J Clin Pathol 1966;19:352-6.

${ }^{12}$ Warrick GR, Albers JJ. A comprehensive evaluation of the heparin manganese precipitation procedure for estimating high density lipoprotein cholesterol. $J$ Lipid Res 1978;19:6576.

${ }^{13}$ Fenech A, Winter JH, Bennett B, Smith FW, Douglas AS. Preoperative frequency of deep venous thrombosis in patients with fractured neck of femur. Lancet 1981;i:1212.

${ }^{14}$ Nilson DWT, Jeremic M, Weisert OK. An attempt at predicting postoperative deep vein thrombosis by preoperative coagulation studies in patients undergoing total hip replacement. Thromb Haemost 1980;43:194-7.

15 Jørgensen KA, Stofferson E, Sørensen PJ, Ingeberg S, Hüttel M, Ahlbom G. Alterations in plasma antithrombin III following total hip replacement and elective cholecystectomy. Scand $J$ Haematol 1980;24:101-4.

16 Yin ET. Effect of heparin on the neutralization of factor Xa and thrombin by plasma alpha-2-globulin inhibitor. Thrombosis et Diathesis Haemorrhagica 1975;33:43-50

Requests for reprints to: $\mathrm{Dr} \mathrm{JH}$ Winter, Centre for Respiratory Investigation, Glasgow Royal Infirmary, 82 Castle Street, Glasgow G4 0SF, Scotland. 